\title{
ВЛИЯНИЕ ОБРАБОТКИ СЕМЯН СОСНЫ ОБЫКНОВЕННОЙ МИКРОБНЫМИ И ФИТОПРЕПАРАТАМИ НА СОХРАННОСТЬ СЕЯНЦЕВ И СВОЙСТВА ПОЧВЫ В ЛЕСНОМ ПИТОМНИКЕ
}

\author{
(С) 2021 г. О. Э. Пашкеева ${ }^{a, *}$, И. Д. Гродницкая ${ }^{a}$, Г. И. Антонов ${ }^{a}$, \\ О. И. Ломовский ${ }^{b}$, И. И. Гайдашева ${ }^{c}$ \\ ${ }^{a}$ Институт леса им. В.Н. Сукачева СО РАН, Академгородок, 50/28, Красноярск, 660036 Россия \\ ${ }^{b}$ Институт химии твердого тела и механохимии СО РАН, ул. Кутателадзе, 18, Новосибирск, 630128 Россия \\ ${ }^{c}$ Сибирский федеральный университет, Свободный просп., 79, Красноярск, 660041 Россия \\ *E-mail: koeandkoe@mail.ru \\ Поступила в редакцию 25.06.2019 г. \\ После доработки 24.01.2020 г. \\ Принята к публикации 08.12.2020 г.
}

\begin{abstract}
Исследования проводили на территории опытного питомника экспериментально-опытного хозяйства “Погорельский бор” Института леса им. В.Н. Сукачева СО РАН. В модельных полевых экспериментах изучали влияние предпосевной обработки семян сосны обыкновенной (Pinus sylvestris L.) водными суспензиями аборигенных микроорганизмов, обладающих антагонистической активностью к фитопатогенам, и фитопрепаратами, полученными из растительного сырья, на микробную биомассу, ферментативную активность почвы и сохранность сеянцев хвойных. Обработку семян сосны проводили штаммами микромицетов Trichoderma harzianum, T. longibrachiatum, T. lignorum, их смесью; бактериями Bacillus amyloliquefaciens, смесью бактерий (B. amyloliquefaciens, B. subtilis, Pseudomonas sp.) и фитопрепаратами (пять вариантов). Показано, что предпосевная обработка семян сосны способствовала улучшению их всхожести, сохранности сеянцев к концу сезона вегетации, морфометрических параметров сеянцев по сравнению с контролем в среднем на $25 \%$. Интродуцированные с семенами популяции бактерий и микромицетов повышали продуктивность, содержание микробной биомассы и ферментативную активность почвы лесного питомника в 1.32.0 раза. Установлено, что в контрольной почве на протяжении всего периода вегетации преобладала олиготрофная группа микроорганизмов, а при обработке семян сосны (микроорганизмы и фитопрепараты) уже через два месяца после посева семян доминировала гидролитико-копиотрофная группа. Внесение микробов-антагонистов (B. amyloliquefaciens, T. longibrachiatum, Смесь бактерий) и фитопрепаратов также благоприятно влияло на функционирование почвенного микробного сообщества, что проиллюстрировано уменьшением значений микробного метаболического коэффициента в среднем почти в 2 раза по сравнению с контролем. Результаты исследования можно рекомендовать для использования в практике лесного хозяйства при выращивании сеянцев хвойных.
\end{abstract}

Ключевые слова: Красноярская лесостепь, сеянцы хвойных, опытный лесной питомник, микроорганизмыантагонисты, фитопрепараты, механохимическая переработка растительного сырья.

DOI: $10.31857 / \mathrm{S} 0024114821020066$

Почвы лесных питомников, предназначенные для выращивания лесопосадочного материала, подвергаются антропогенному воздействию (вспашка, внесение пестицидов, монокультура, изъятие растительности), что негативно сказывается на их плодородии, в том числе в виде уменьшения содержания питательных элементов (истощение), увеличения токсикогенности и численности фитопатогенных микроорганизмов (Громовых и др., 2002; Фомина и др., 2006; Trasar-Cepeda et al., 2008). Кроме того, в почве наблюдается развитие деградационных процессов, изменение ее кислотно-щелочных свойств, количественного и ка- чественного состава микробиоты, снижение ферментативной активности и увеличение количества патогенных микроорганизмов (Фомина и др., 2006; Гродницкая, Сорокин, 2007).

Для решения этих проблем актуальным является использование биологических методов восстановления почв с помощью растений и микроорганизмов, способных не только восстановить, но и существенно улучшить состояние деградированных и нарушенных почв, увеличить адаптационный потенциал растений именно на ранних этапах формирования фитоценоза, когда гибель растений наиболее высока. Применение смесей 
порошков растительного сырья, полученных после механохимической обработки, приводит к увеличению реакционной способности субстрата в качестве источника биологически активных веществ для полезной микробиоты почвы (Рожанская и др., 2007). Микроорганизмы являются одним из главных экологических факторов почвообразования, способствуют восстановлению деградированных почв за счет приведения основных физических, химический и биологических параметров к оптимальным показаниям. Поэтому внесение их в почву приводит к ускорению процессов деградации или детоксикации опасных субстратов до безопасных для почвенной биоты и растений (Ваset et al., 2010; Solevic et al., 2011).

С помощью микробиологических индикаторов можно провести адекватную оценку плодородия почвы (биологической активности), по их значениям оценивают важнейшие почвенные процессы: скорость разложения органических веществ, дыхание и биохимическую активность (Anderson J., Domsch, 1978; Ананьева, 2003; Хазиев, 2005; Стольникова и др., 2011). Микробная биомасса (МБ) (живая часть органического углерода), базальное (БД) и удельное $\left(q \mathrm{CO}_{2}\right)$ дыхание определяют экофизиологическое состояние (статус) почвенного микробного сообщества, дают своеобразную качественную оценку почвы (Harris, 2003). Изменение величины $q \mathrm{CO}_{2}$ почвы в сторону увеличения отмечается под воздействиями природных стрессов (высушивание - увлажнение, замораживание - оттаивание), а также при различных антропогенных нарушениях, в том числе загрязнении тяжелыми металлами и пестицидами при многолетнем возделывании монокультуры сельскохозяйственных растений (Anderson T., Domsch, 1990; Ананьева, 2003; Gibbs et al., 2006). Соотношение эколого-трофических групп микроорганизмов (ЭКТГМ) и ферментативная активность почвы позволяют оценивать направление деструкционных процессов в ту или иную сторону (гумусонакопления или истощения) и скорость биохимических процессов. На основании количественных показателей микробиологических индикаторов можно осуществлять мониторинг состояния антропогенно нарушенных экосистем с целью их оценки, контроля или прогноза.

Цель настоящего исследования - изучить влияние предпосевной обработки семян сосны обыкновенной микроорганизмами-антагонистами и фитопрепаратами на сохранность сеянцев хвойных, биологическую активность темно-серой почвы лесного питомника.

\section{ОБЪЕКТЫ И МЕТОДИКА}

Полевые эксперименты по исследованию влияния микробов-антагонистов и фитопрепаратов на биологическую активность, рост и развитие семян сосны обыкновенной проводили в опытном питомнике экспериментально-опытного хозяйства "Погорельский бор" Института леса им. В.Н. Сукачева СО РАН в 2016 г. Погорельский бор - интразональный участок Красноярской лесостепи, расположенный в 40 км к северу от г. Красноярск $\left(56^{\circ} 22^{\prime}\right.$ с.ш. $/ 92^{\circ} 57^{\prime}$ в.д.), почва темно-серая (WRB, Albic LUVISOLS/Grey-Luvic PHAEOZEMS) слабо-оподзоленная оглееная, тяжелосуглинистая, с удовлетворительным состоянием гумусового горизонта и хорошо обеспеченная элементами питания растений (Сорокин и др., 2009; Антонов и др., 2018). Экологические условия произрастания фитоценозов Погорельского бора (данные специалистов Института леса СО РАН) довольно благоприятные (последние 40 лет нет систематического загрязнения), с невысокими рекреационными нагрузками.

В гранулометрическом составе минерального профиля почвы преобладают фракции мелкого песка. Лесная подстилка (O, 0-1(2) см) характеризуется слабокислой реакцией среды $\left(\mathrm{pH}_{\text {водн }} 5.1\right)$, в горизонтах AEL и BEL pH достигал 5.91 и 6.00 coответственно, в горизонте ВТ - 5.88. Содержание $\mathrm{C}_{\text {орг }}$ снижается с глубиной: так, в горизонте $\mathrm{AU}-$ 5-15 см $\mathrm{C}_{\text {орг }}$ составило 4.4\% (среднее значение), в AU - 20-30 см - 3.05\% (ниже среднего), а затем оно резко снижается в нижележащих горизонтах. Отношение C : N в слое 5-20 см составило 57, 2030 см - 41, 35-45 см - 6 (Антонов и др., 2018).

Всхожесть семян сосны обыкновенной (Pinus sylvestris L.) определяли в лабораторных условиях по методике А.И. Новосельцева и В.А. Смирнова (1983). Затем семена сосны обрабатывали суспензиями микробов-антагонистов и фитопрепаратами. Штаммы микробов-антагонистов (Bacillus amyloliquefaciens, B. subtilis, Pseudomonas sp., Trichoderma longibrachiatum, T. lignorum) взяты из музея лаборатории микробиологии и экологической биотехнологии института леса СО РАН, микромицет Trichoderma harzianum (Rifai) получен в виде препарата “триходермин” из Сибирского федерального университета (г. Красноярск). Биологическая активность этих штаммов проверена и описана нами ранее (Кондакова, Гродницкая, 2018). Готовили водные суспензии микромицетов Trichoderma harzianum, T. longibrachiatum, T. lignorum $\left(10^{7-8}\right.$ спор мл $\left.{ }^{-1}\right)$ и бактерий Bacillus amyloliquefaciens, B. subtilis, Pseudomonas sp. $\left(10^{7-8}\right.$ кл мл $\left.{ }^{-1}\right)$ (Rovira, 1965; Новосельцева, Смирнов, 1983). Растительный препарат (фитопрепарат, 10 г) растворяли в воде (1 л), осадок раствора не использовали. Фитопрепараты (всего 5) получали механохимической обработкой смеси растительного сырья (порошок) и реагентов, указанных в его составе. Механохимическая обработка растительного сырья включала его измельчение (мельница-активатор 
АГО-2, стальные шары диаметром 5 мм с расчетным ускорением 200 м с $^{-2}$ в течение 2 мин) и высушивание до порошкообразного состояния. Получали фитопрепататы (ФП) с повышенным содержанием биологически активных веществ: шелуха гречихи $+5 \% \mathrm{NaOH}(Ф П 1)-$ полифенол меланина; шелуха риса + зеленый чай (ФП2) хелаты галлокатехинов зеленого чая и оксида кремния; шелуха риса + шелуха гречихи (ФП3) хелаты меланина и оксида кремния; бурый уголь + $+\mathrm{NaOH}(Ф П 4)$ - высокомолекулярные полифенолы (гуматы натрия); бурый уголь + ламинария (ФП5, производство США-Китай). После механохимической обработки фитопрепаратов в них определяли содержание уже упомянутых водорастворимых активных веществ (Рожанская и др., 2007; Shapolova, Lomovsky, 2016).

Предпосевная обработка семян заключалась в их замачивании в $0.05 \%$-ом растворе $\mathrm{KMnO}_{4}$ в течение 6 ч и затем - суспензиях микробов-антагонистов и растворах фитопрепаратов (3 ч). Семена, обработанные $0.05 \%$-ом раствором $\mathrm{KMnO}_{4}$ и помещенные затем в стерильную воду на 3 ч, служили контролем.

Обработанные таким образом семена сосны обыкновенной высевали в почву (150 шт. в три посевные строки, всего 450) опытных участков $(50 \times 50$ см, всего 11). Варианты эксперимента: ФП1; ФП2; ФП3; ФП4; ФП5; обработка T. harzianum; T. longibrachiatum; Смесь грибов p. Trichoderma (T. harzianum, T. lignorum, T. longibrachiatum); B. amyloliquefaciens; Смесь бактерий (Bacillus amyloliquefaciens, B. subtillis, Pseudomonas sp.); контроль - $\mathrm{H}_{2} \mathrm{O}$. После посева семян почву опытных участков мульчировали опилками слоем до 2 см. Грунтовую всхожесть семян учитывали через 30 сут, а численность сеянцев сосны - ежемесячно в течение всего периода вегетации (июнь-сентябрь). По окончании эксперимента сеянцы (по 10 шт. каждого варианта) отбирали для их биометрического исследования.

До формирования экспериментальных участков и посева семян отбирали образцы почвы (горизонт AU 0-15 см, смешанный образец из трех точек) для анализа ее начальных (фоновых) показателей, затем ежемесячно - для микробиологических анализов. Отбор образцов почв для определения их ферментативной активности проводили в начале и конце вегетации растений.

На каждом участке при отборе почвенных образцов измеряли температуру воздуха и почвы с использованием портативного термометра "Hanna Checktemp 1". В лабораторных условиях термостатно-весовым методом определяли влажность почвы. Значения $\mathrm{pH}$ (почва/вода = $1: 10)$ определяли портативным потенциометром “Аквилон-410”.

Отбор почвы для микробиологических и ферментативных анализов проводили с глубины 0-
15 см. Один смешанный образец почвы в каждом варианте опыта составляли из трех прикопок на участке. Для микробиологических анализов использовали свежеотобранные образцы, а для определения ферментов - высушенные. Численность, структуру и таксономический состав ЭКТГМ определяли методом посева почвенной суспензии на элективные агаризованные питательные среды (Методы ..., 2003; Практикум ..., 2005). Гидролитические бактерии учитывали на мясопептонном агаре (МПА), копиотрофы крахмало-аммиачном агаре (КАA), олиготрофы почвенном агаре (ПА), микроскопические грибы сусло-агаре (СА+ молочная кислота, 4 мл $\left.\pi^{-1}\right)$. Посев почвенной суспензии (0.1 мл, разведение $\left.1: 10^{3}\right)$ проводили на поверхность указанных питательных сред (3 повторности) на следующий день после отбора образцов. Чашки Петри с посевом инкубировали при $27-28^{\circ} \mathrm{C}$. Подсчет численности бактерий проводили на 2-3-е, грибов - 47-е сутки инкубирования. Подсчитывали численность колониеобразующих единиц (KOE) в 1 г почвы (Практикум ..., 2005). Рассчитывали коэффициент микробиологической минерализации $\left(K_{\text {мин }}=\right.$ КАА : МПА), иллюстрирующий разложение и накопление органических веществ. Коэффициент олиготрофности $\left(K_{\text {олиг }}=\right.$ ПА : МПА) иллюстрирует способность микроорганизмов к аккумуляции питательных элементов из “рассеянного” состояния (Мишустин, Емцев, 1987).

Ферментативную активность почвы с использованием фотоэлектроколориметра КФК-3 определяли по методикам, описанным Ф.Х. Хазиевым (2005). Активность гидролитических ферментов (инвертазы, протеазы, уреазы, фосфатазы) определяли при компостировании почвы в термостате при $30-38^{\circ} \mathrm{C}$ в течение 3-24 ч. Активность пероксидазы (ПО) и полифенолоксидазы (ПФО) определяли по методу Л.А. Карягиной и Н.А. Михайловой (Хазиев, 2005). Активность ферментов выражали на единицу веса почвы (г): инвертазы - мг глюкозы, уреазы - мг $\mathrm{N}-\mathrm{NH}_{4}$, фосфатазы - мг $\mathrm{P}_{2} \mathrm{O}_{5}$, ПФО и ПО - 1.4-парабензохинона. По отношению активности ПФО и ПО рассчитывали коэффициент гумификации $\left(K_{\text {гум }}\right)$, позволяющий судить об интенсивности процесса минерализации гумуса (Методы ..., 2003; Хазиев, 2005). Размерность ферментов обозначали как единица фермента (ед. ф.) далее по тексту.

Дыхательную активность почвенного микробного сообщества измеряли с использованием газового хроматографа Agilent Technologies $6890 \mathrm{~N}$ Network GC (USA) и выражали скоростью БД и субстрат-индуцированного дыхания (СИД) (Anderson J., Domsch, 1978; Ананьева, 2003). Значения СИД использовали для расчета углерода МБ, выраженной содержанием углерода $\left(\mathrm{C}_{\text {мик }}\right)$. 
Корреляционную связь между эколого-трофическими группами микроорганизмов почвы и ее температурой, $\mathrm{pH}$, влажностью оценивали коэффициентами $(r)$ Пирсона (данные с нормальным распределением) и Спирмена (распределение отличается от нормального). Эти коэффициенты значимы при доверительной вероятности 95 и $99 \%$. Зависимость между микробными и почвенными показателями оценивали дисперсионным и корреляционным анализами. Для оценки различий и сходства между вариантами обработки семян и контролем использовали метод построения сетей схожести (Network plot) со срезом сходства 60 и $70 \%$ (метод главных компонент и кластерный анализ). Полученные данные обработаны при помощи статистического пакета программ Microsoft Excel 2015, Statistica 12.

\section{РЕЗУЛЬТАТЫ И ОБСУЖДЕНИЕ}

Химические и микробиологические свойства почвы, представлены в табл. 1. Почва фона характеризуется слабо-кислой, близкой к нейтральной реакцией среды (рН 6.4), низкой влажностью $11.9 \%$, средняя температура за вегетационный сезон $-19.2^{\circ} \mathrm{C}$. В фоновой почве численность гидролитиков, копиотрофов и олиготрофов состави-

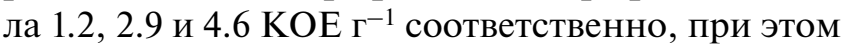
численность олиготрофов превышала таковую гидролитиков в 3.8 раз. Значение $K_{\text {олиг }}$ в этой почве превышало в среднем в 1.6 раза $K_{\text {мин }}$, что свидетельствовало об ослаблении минерализационных процессов. К тому же численность актиномице-

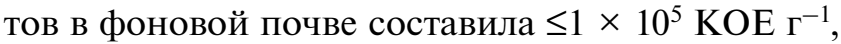
что также свидетельствует о низкой степени минерализации органических веществ. Микромицеты в почве фона (май) не были обнаружены. В темно-серой почве фонового участка содержание МБ составило 133 мкг $\mathrm{C}^{-1}$, значение $q \mathrm{CO}_{2}$ довольно высокое (20 мкг С- $\mathrm{CO}_{2} \mathrm{M \Gamma}^{-1} \mathrm{C}_{\text {мик }} \mathrm{\Psi}^{-1}$, что может свидетельствовать о нарушении функционирования микробоценоза (Ананьева, 2003; Ананьева и др., 2011; Стольникова и др., 2011).

Посев семян сосны, обработанных микробами-антагонистами и фитопрепаратами, проводили в конце мая (температура почвы $11^{\circ} \mathrm{C}$, воздуха $28^{\circ} \mathrm{C}$, влажность почвы $\left.18.9 \%\right)$. Лабораторная всхожесть семян составила $30 \%$, а грунтовая (июнь) $-3-23 \%$ (табл. 1). Такая низкая всхожесть в естественных условиях связана, скорее всего, с неблагоприятными климатическими условиями. Так, согласно данным дневника погоды ГИСМЕТЕОЦЕНТР, в июне дневная температура не опускалась ниже $18^{\circ} \mathrm{C}, 24$ дня этого месяца воздух прогревался $\geq 24^{\circ} \mathrm{C}$, и только 7 дней были с осадками (https://www.gismeteo.ru/diary/4674/2016/6/). Наибольшую грунтовую всхожесть семян сосны $(23 \%)$ отмечали в контроле и при обработке
T. harzianum. При обработке фитопрепаратами всхожесть семян была выше в варианте ФП3 (12\%), бактерий - B. amyloliquefaciens (17\%) (табл. 1).

Иссушение почвы (особенно в июне-начале июля) привело к гибели значительного количества сеянцев $(r=-0.6, p<0.05)$, которое еще снизилось на $50 \%$ к концу вегетационного сезона во всех вариантах опыта. Однако наибольшая и почти одинаковая сохранность сеянцев оказалась в контроле и при обработке T. harzianum (15.6 и 15.7\% соответственно). Количество сеянцев в вариантах B. amyloliquefaciens и ФП1 снизилось в 2 раза, составляя 7.6 и $2.4 \%$ соответственно (табл. 1). Обработка семян сосны фитопрепаратами также способствовала увеличению их грунтовой всхожести по сравнению с контролем. Однако сохранность сеянцев к концу вегетации была выше при обработке микробными препаратами (особенно в вариантах с B. amyloliquefaciens и Смесью бактерий).

Морфометрический анализ растений выявил, что длина корешков сеянцев была выше в контроле в среднем на $22 \%$ по сравнению с другими вариантами. Микроорганизмы B. amyloliquefaciens и T. harzianum стимулировали рост диаметра корневой шейки сеянцев по сравнению с контролем в среднем на 14.6 и 100\%. При обработке препаратом ФП1 диаметр корневой шейки сеянцев оказался меньше на $17.5 \%$ по сравнению с таковым при микробной обработке (табл. 2). Длина мутовки сеянцев сосны была в 2.6 раз выше при обработке B. amyloliquefaciens и T. harzianum, но в 1.4 раза меньше при ФП1 $(p<0.05)$ по сравнению с контролем. Вес сеянцев в вариантах ФП1 и $B$. amyloliquefaciens был в 6.5 раз больше, чем в контроле (табл. 2). Отмечено, что на количество сеянцев сосны и их морфометрические показатели большее влияние оказывала влажность почвы $(r=0.61)$.

Таким образом, на грунтовую всхожесть семян и морфометрические характеристики сеянцев сосны обыкновенной положительное влияние оказала предпосевная обработка штаммами микроорганизмов $T$. harzianum, B. amyloliquefaciens и фитопрепаратом № 1. Мы полагаем, что при обработке семян микроорганизмами и фитопрепаратами (начальный этап их развития) происходит взаимодействие корней растений и аборигенной микрофлоры, что способствует формированию более устойчивых трофических связей в системе “почва-растение".

Показано, что в почве с посевами сосны обыкновенной преобладала олиготрофная группа микроорганизмов, значение $K_{\text {олиг }}$ было в 1.5 раза

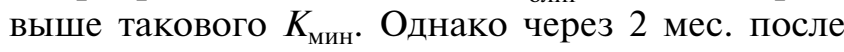
посева семян в вариантах с фитопрепаратами и бактериями, напротив, преобладали гидролитико-копиотрофные микроорганизмы $\left(K_{\text {мин }}>K_{\text {олиг }}\right.$ в 1.5 раза). Возможно, это связано с высокой гибелью всходов сосны и поступлением в почву 
Таблица 1. Значения основных параметров темно-серой почвы в органогенном горизонте (0-15 см) и доля сеянцев сосны разных вариантов опыта в течение вегетационного сезона на опытном питомнике

\begin{tabular}{|c|c|c|c|c|c|c|c|c|c|c|c|c|}
\hline \multirow[t]{2}{*}{ Вариант опыта } & \multirow[t]{2}{*}{$\mathrm{pH}$} & \multirow[t]{2}{*}{$t,{ }^{\circ} \mathrm{C}$} & \multirow[t]{2}{*}{ ВЛ, \% } & \multicolumn{3}{|c|}{$\begin{array}{c}\text { Численность микроорганизмов, } \\
\text { млн КОЕ } \Gamma^{-1} \text { почвы }\end{array}$} & \multirow[t]{2}{*}{$K_{\text {мин }}$} & \multirow[t]{2}{*}{$K_{\text {олиг }}$} & \multirow[t]{2}{*}{$\mathrm{C}_{\text {мик }}$} & \multirow[t]{2}{*}{ БД } & \multirow[t]{2}{*}{$q \mathrm{CO}_{2}$} & \multirow[t]{2}{*}{$\begin{array}{c}\text { ДСС, } \\
\%\end{array}$} \\
\hline & & & & гд & КП & ОЛ & & & & & & \\
\hline \multicolumn{13}{|c|}{ Май } \\
\hline Фон & 6.4 & 11.2 & 18.9 & 1.2 & 2.9 & 4.6 & 2.4 & 3.9 & 133 & $|2.7|$ & 20 & - \\
\hline \multicolumn{13}{|c|}{ Июнь } \\
\hline Контроль $\left(\mathrm{H}_{2} \mathrm{O}\right)$ & 6.8 & 18.5 & 15.6 & 0.2 & 1.3 & 1.8 & 5.6 & 7.9 & 143 & $4.8 \mid$ & 33 & 34.7 \\
\hline ФП1 & 6.5 & 18.3 & 16.3 & 0.2 & 0.8 & 1.5 & 3.5 & 6.5 & 172 & 5.2 & 30 & 4.7 \\
\hline ФП2 & 6.7 & 18.3 & 13.4 & 2.2 & 3.4 & 2.0 & 1.6 & 0.9 & 219 & 11.9 & 55 & 8.3 \\
\hline ФП3 & 7.0 & 18.6 & 17.6 & 0.2 & 1.9 & 1.8 & 8.0 & 7.5 & 117 & 6.3 & 54 & 6.0 \\
\hline ФП4 & 6.6 & 18.8 & 17.2 & 1.7 & 2.6 & 2.1 & 1.5 & 1.2 & 361 & 8.1 & 23 & 17.3 \\
\hline ФП5 & 6.5 & 18.5 & 16.6 & 0.2 & 1.3 & 3.1 & 5.2 & 6.7 & 269 & 7.1 & 27 & 6.3 \\
\hline Trichoderma harzianum & 6.6 & 18.4 & 14.3 & 0.2 & 1.3 & 2.0 & 7.2 & 10.9 & 178 & 4.5 & 25 & 34.7 \\
\hline T. longibrachiatum & 6.6 & 18.5 & 17.3 & 0.2 & 0.9 & 1.8 & 5.6 & 10.8 & 263 & 7.4 & 28 & 3.7 \\
\hline Смесь микромицетов & 6.7 & 18.5 & 15.5 & 0.3 & 0.3 & 1.6 & 1.0 & 4.9 & 159 & 5.4 & 34 & 4.3 \\
\hline Bacillus amyloliquefaciens & 7.7 & 18.5 & 17.3 & 0.1 & 1.9 & 0.9 & 30.5 & 13.3 & 179 & 7.8 & 43 & 25.7 \\
\hline Смесь бактерий & 6.9 & 18.8 & 15.9 & 0.3 & 2.3 & 3.8 & 8.3 & 13.5 & 218 & 9.3 & 42 & 4.7 \\
\hline \multicolumn{13}{|c|}{ Июль } \\
\hline Контроль $\left(\mathrm{H}_{2} \mathrm{O}\right)$ & 7.1 & 25.3 & 13.4 & 0.2 & 1.9 & 1.2 & 8.3 & 5.5 & 149 & 5.8 & 39 & 27.67 \\
\hline ФП1 & 7.1 & 24.3 & 14.5 & 0.2 & 1.3 & 0.6 & 8.5 & 4.0 & 124 & 8.1 & 66 & 4.00 \\
\hline ФП2 & 7.0 & 24.5 & 11.2 & 1.0 & 1.5 & 1.2 & 1.5 & 1.1 & 164 & 9.7 & 59 & 1.67 \\
\hline ФП3 & 7.3 & 25.2 & 16.7 & 0.4 & 1.1 & 1.7 & 2.9 & 4.5 & 103 & 4.5 & 44 & 0.67 \\
\hline ФП4 & 7.1 & 26.4 & 15.6 & 0.2 & 1.3 & 0.8 & 5.7 & 3.3 & 177 & 6.5 & 37 & 5.33 \\
\hline ФП5 & 6.7 & 23.7 & 15.4 & 0.2 & 1.8 & 1.1 & 7.5 & 4.7 & 140 & 5.9 & 42 & 3.67 \\
\hline Trichoderma harzianum & 6.9 & 24.2 & 15.5 & 0.3 & 0.7 & 0.9 & 2.1 & 2.8 & 168 & 6.7 & 40 & 24.67 \\
\hline T. longibrachiatum & 7.3 & 24.5 & 16.7 & 0.4 & 1.7 & 2.3 & 4.1 & 5.8 & 175 & 4.3 & 25 & 0.33 \\
\hline Смесь микромицетов & 6.8 & 25.2 & 15.4 & 0.1 & 0.7 & 0.9 & 5.1 & 7.4 & 224 & 8.5 & 38 & 1.33 \\
\hline Bacillus amyloliquefaciens & 7.0 & 24.4 & 14.7 & 0.1 & 1.4 & 0.9 & 10.8 & 7.2 & 173 & 4.8 & 28 & 8.67 \\
\hline Смесь бактерий & 6.9 & 24.4 & 13.1 & 1.3 & 1.6 & 1.6 & 1.3 & 1.3 & 184 & 8.2 & 45 & 2.33 \\
\hline \multicolumn{13}{|c|}{ Август } \\
\hline Контроль $\left(\mathrm{H}_{2} \mathrm{O}\right)$ & 6.4 & 13.7 & 17.3 & 1.3 & 2.5 & 2.7 & 2.0 & 2.0 & 249 & 7.8 & 31 & 21.33 \\
\hline ФП1 & 6.4 & 13.8 & 18.2 & 1.1 & 3.5 & 3.7 & 3.2 & 3.4 & 228 & 4.2 & 19 & 4.00 \\
\hline ФП2 & 6.6 & 13.7 & 19.4 & 2.3 & 3.9 & 4.0 & 1.7 & 1.7 & 113 & 4.1 & 36 & 1.00 \\
\hline ФП3 & 6.6 & 13.8 & 18.4 & 1.7 & 2.3 & 2.4 & 1.4 & 1.5 & 148 & 6.3 & 43 & 0.67 \\
\hline ФП4 & 6.6 & 13.9 & 18.3 & 0.8 & 0.7 & 4.1 & 0.9 & 5.3 & 170 & 3.9 & 23 & 2.67 \\
\hline ФП5 & 6.8 & 13.8 & 19.4 & 2.3 & 1.4 & 3.1 & 0.6 & 1.4 & 162 & 3.2 & 20 & 2.67 \\
\hline Trichoderma harzianum & 6.9 & 13.7 & 13.6 & 1.6 & 1.3 & 2.0 & 0.8 & 1.3 & 177 & 5.4 & 31 & 21.00 \\
\hline T. longibrachiatum & 6.3 & 13.7 & 18.0 & 1.8 & 1.2 & 2.7 & 0.6 & 1.5 & 152 & 3.8 & 25 & 0.33 \\
\hline Смесь микромицетов & 6.5 & 13.5 & 15.9 & 1.0 & 0.8 & 2.4 & 0.7 & 2.3 & 173 & 3.0 & 17 & 1.33 \\
\hline Bacillus amyloliquefaciens & 6.6 & 13.9 & 17.6 & 1.3 & 2.0 & 3.1 & 1.5 & 2.3 & 135 & 6.3 & 47 & 12.00 \\
\hline Смесь бактерий & 7.3 & 13.8 & 19.1 & 4.6 & 2.5 & 4.7 & 0.6 & 1.0 & 213 & 4.4 & 21 & 2.67 \\
\hline
\end{tabular}


Таблица 1. Окончание

\begin{tabular}{|c|c|c|c|c|c|c|c|c|c|c|c|c|}
\hline \multirow[t]{2}{*}{ Вариант опыта } & \multirow[t]{2}{*}{$\mathrm{pH}$} & \multirow[t]{2}{*}{$t,{ }^{\circ} \mathrm{C}$} & \multirow[t]{2}{*}{ ВЛ, \% } & \multicolumn{3}{|c|}{$\begin{array}{c}\text { Численность микроорганизмов, } \\
\text { млн КОЕ } \Gamma^{-1} \text { почвы }\end{array}$} & \multirow[t]{2}{*}{$K_{\text {мин }}$} & \multirow[t]{2}{*}{$K_{\text {олиг }}$} & \multirow[t]{2}{*}{$\mathrm{C}_{\text {мик }}$} & \multirow[t]{2}{*}{ БД } & \multirow[t]{2}{*}{$q \mathrm{CO}_{2}$} & \multirow[t]{2}{*}{$\begin{array}{l}\text { ДСС, } \\
\%\end{array}$} \\
\hline & & & & Гд & КП & ОЛ & & & & & & \\
\hline \multicolumn{13}{|c|}{ Сентябрь } \\
\hline Контроль $\left(\mathrm{H}_{2} \mathrm{O}\right)$ & 7.1 & 20.1 & 13.1 & 0.4 & 0.8 & 1.3 & 2.2 & 3.5 & 159 & 4.3 & 27 & 23.67 \\
\hline ФП1 & 6.7 & 19.5 & 17.9 & 0.9 & 0.8 & 1.7 & 0.91 & 2.0 & 227 & 4.5 & 20 & 3.67 \\
\hline ФП2 & 6.5 & 20.2 & 16.5 & 1.3 & 2.2 & 2.8 & 1.69 & 2.2 & 199 & 4.3 & 22 & 1.00 \\
\hline ФП3 & 6.6 & 18.5 & 16.3 & 1.0 & 0.9 & 1.2 & 0.85 & 1.2 & 126 & 3.9 & 31 & 0.67 \\
\hline ФП4 & 7.1 & 21.5 & 19.1 & 0.2 & 0.4 & 1.3 & 1.47 & 5.2 & 216 & 3.0 & 14 & 1.67 \\
\hline ФП5 & 6.6 & 20.9 & 17.0 & 1.0 & 1.2 & 2.0 & 1.19 & 2.0 & 243 & 3.6 & 15 & 2.33 \\
\hline Trichoderma harzianum & 6.6 & 19.3 & 16.2 & 0.8 & 1.2 & 2.4 & 1.72 & 3.5 & 227 & 3.1 & 14 & 23.33 \\
\hline T. longibrachiatum & 6.7 & 20.5 & 19.6 & 0.3 & 0.3 & 1.9 & 0.92 & 5.9 & 170 & 5.0 & 29 & 0.33 \\
\hline Смесь микромицетов & 6.5 & 20.4 & 18.1 & 0.3 & 1.4 & 1.0 & 4.91 & 3.7 & 118 & 3.4 & 29 & 1.33 \\
\hline Bacillus amyloliquefaciens & 6.8 & 19.4 & 19.0 & 0.3 & 1.5 & 2.5 & 5.11 & 9.0 & 232 & 5.0 & 22 & 11.33 \\
\hline Смесь бактерий & 6.6 & 18.2 & 18.6 & 1.7 & 2.7 & 3.5 & 1.63 & 2.1 & 257 & 4.7 & 18 & 2.67 \\
\hline
\end{tabular}

Примечание. $\mathrm{pH}$ - кислотность почвы, $t$ - температура почвы, ВЛ - влажность, ГД - численность гидролитических микроорганизмов, КП - численность копиотрофных микроорганизмов, ОЛ - численность олиготрофных микроорганизмов, $K_{\text {мин }}-$ коэффициенты минерализации и $K_{\text {олиг }}-$ коэффициент олиготрофности, С микробной биомассы (мкг $\left.\mathrm{C}^{-1}\right)$, БД - базальное дыхание (мкг С- $\left.\mathrm{CO}_{2} \Psi^{-1} \Gamma^{-1}\right), q \mathrm{CO}_{2}-$ микробный метаболический коэффициент (мкг С-CO $\mathrm{CO}_{2}{ }^{-1} \mathrm{C}_{\text {мик }}{ }^{-1}$ ), ДСС - доля сеянцев сосны.

Таблица 2. Морфометрические показатели сеянцев сосны в некоторых вариантах опыта $(n=10)$

\begin{tabular}{|c|c|c|c|c|c|}
\hline \multirow{2}{*}{ Вариант } & \multicolumn{3}{|c|}{ Длина, см } & \multirow{2}{*}{$\begin{array}{c}\text { Диаметр корневой } \\
\text { шейки, мм }\end{array}$} & \multirow{2}{*}{ Вес (сухой) сеянца, , } \\
\hline & мутовка & стебелек & корень & & \\
\hline Контроль & $0.32 \pm 0.2$ & $3.2 \pm 0.2$ & $10.0 \pm 1.2$ & $0.32 \pm 0.02$ & $0.11 \pm 0.02$ \\
\hline ФП1 & $1.2 \pm 0.2$ & $3.3 \pm 0.2$ & $8.5 \pm 0.3$ & $0.26 \pm 0.01$ & $0.14 \pm 0.07$ \\
\hline Trichoderma harzianum & $3.1 \pm 0.25$ & $3.6 \pm 0.09$ & $8.9 \pm 0.3$ & $0.36 \pm 0.01$ & $0.15 \pm 0.01$ \\
\hline Bacillus amyloliquefaciens & $4.3 \pm 0.3$ & $3.5 \pm 0.2$ & $9.04 \pm 0.6$ & $0.70 \pm 0.13$ & $0.16 \pm 0.01$ \\
\hline
\end{tabular}

мертвой органической массы растений. К тому же, показана значимо высокая отрицательная корреляции между количеством погибших проростков (сеянцев) и численностью основных ЭКТГМ ( $r=-0.5-$ для фитопрепаратов и $r=-0.7-$ для бактерий).

Обработка семян сосны смесью микромицетов рода Trichoderma и фитопрепаратами (ФП2-4) способствовала увеличению численности гидролитико-копиотрофного комплекса в 2.7 раз, T. longibrachiatum - гидролитико-олиготрофного в 1.5 раза, а Смесью бактерий - всех ЭКТГМ в 2 раза по сравнению с контролем (табл. 1). Следует отметить, что общая численность микроорганизмов возрастала при увеличении температуры почвы $(r=0.5)$.
В почве опытного питомника численность микроскопических грибов, основных деструкторов органики, была довольно низкой, и только к концу вегетации (август-сентябрь) она возросла в среднем в 3.5 раза. Этот факт может быть связан с увеличением влажности почвы и созданием тем самым благоприятных условий для развития микромицетов. Внесенные с семенами сосны микромицеты (T. harzianum, T. longibrachiatum, Смесь микромицетов) способствовали также увеличению общей численности грибов почвы относительно контроля в 3.7, 1.1 и 1.3 раза соответственно $(p>0.05)$. В других вариантах обработки численность почвенных грибов увеличилась только с внесением смеси бактерий,

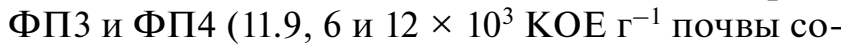
ответственно) (табл. 1). 


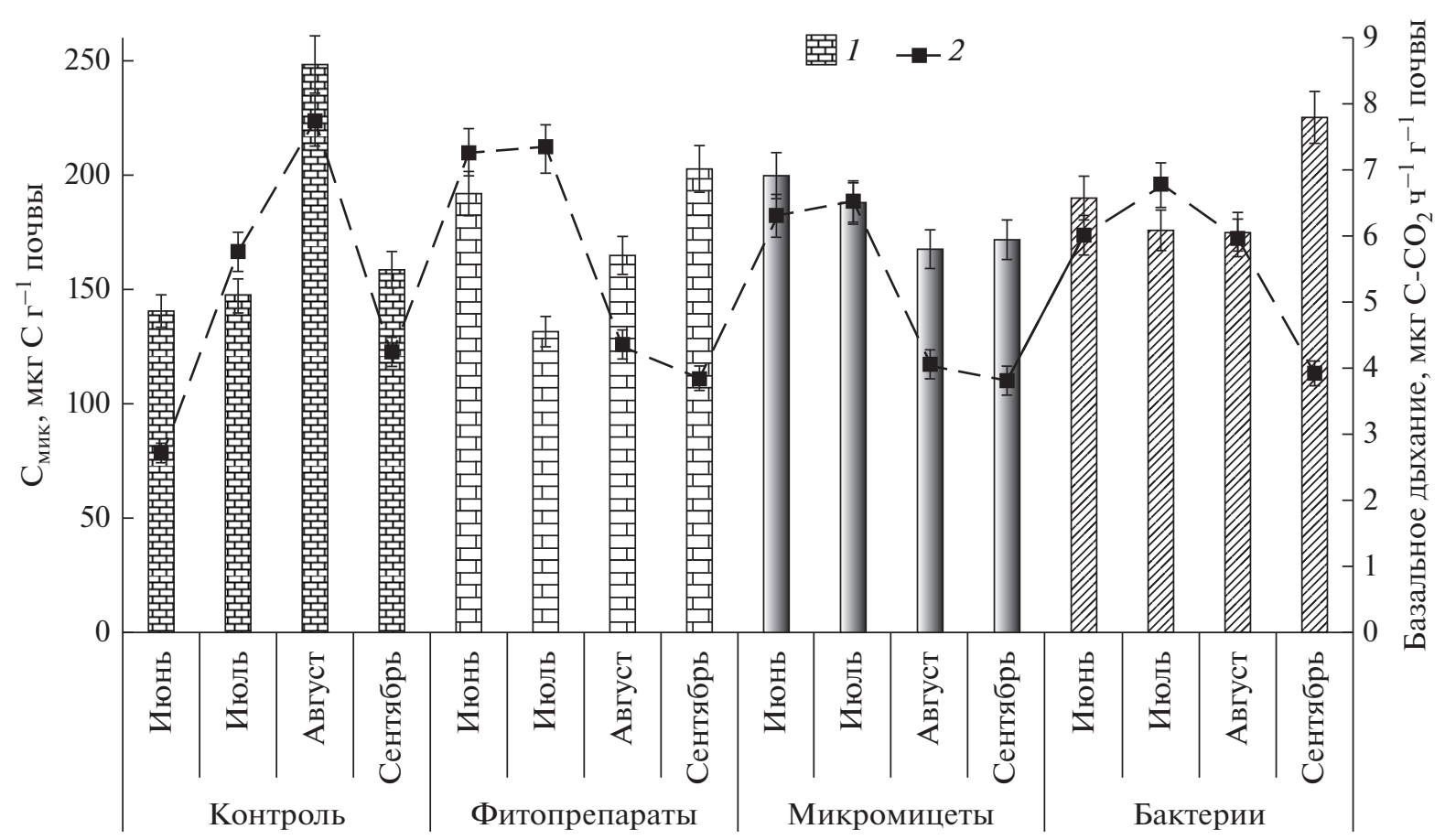

Рис. 1. Изменения значений микробной биомассы (1) и базального дыхания (2) в течение вегетационного периода в почве под посевами хвойных (усредненные данные разных вариантов обработок).

Таким образом, внесенные в почву с семенами сосны обыкновенной микробы-антагонисты и фитопрепараты способствовали увеличению численности ее основных ЭКТГМ на протяжении всего сезона вегетации. Наибольшее стимулирующее влияние на численность микроорганизмов почвы оказывало внесение Смеси бактерий, T. longibrachiatum, B. amyloliquefaciens и ФП3. Причем, внесение микроорганизмов способствовало большему увеличению численности ЭКТГМ и изменению их доминирующей группы по сравнению с фитопрепаратами.

Обработка семян сосны фитопрепаратами (1-3), бактериями (B. amyloliquefaciens, Смесь бактерий) способствовала увеличению содержания МБ и интенсивности почвенного дыхания (табл. 1). Содержание МБ в почве под посевами в сентябре возросло в среднем в 1.5 раза по сравнению с фоновой почвой в вариантах с T. harzianum, B. amyloliquefaciens, Смесью бактерий и фитопрепаратами (№№ 1,4 и 5). Следует отметить, что содержание МБ на протяжении вегетационного сезона было ниже в контрольной почве и в вариантах с фитопрепаратами (рис. 1, табл. 1). Установлено, что на величины МБ и БД наибольшее влияние оказывала температура и влажность почвы ( $r=0.6$ и -0.6 , соответственно), что согласуется с результатами других исследований (Стольникова и др., 2011).

Значения $q \mathrm{CO}_{2}$ почвы в первые два месяца вегетационного сезона (июнь-июль) были достаточно высокими и составили 36 в контроле, 42 и
35 мкг С-CO $\mathrm{M \Gamma}^{-1} \mathrm{C}_{\text {мик }} \mathrm{\Psi}^{-1}$ в вариантах с фитопрепаратами и микроорганизмами, соответственно. Высокие значения коэффициента удельного дыхания могут свидетельствовать о нарушении функционирования микробных сообществ, низкой эффективности использования субстрата (или его малых дозах), микробном стрессе (Ананьева и др., 2009). К сентябрю значения $q \mathrm{CO}_{2}$ в почве снизились в среднем в $1.5-2$ раза по сравнению с июнем, причем они были наименьшими в вариантах с микроорганизмами и фитопрепаратами (23 и 20 мкг С- $\mathrm{CO}_{2}$ мГ $^{-1} \mathrm{C}_{\text {мик }} \mathrm{ч}^{-1}$ (табл. 1).

Таким образом, уменьшение $q \mathrm{CO}_{2}$ в почве под посевами сосны обыкновенной может свидетельствовать, о том что микробное сообщество “стремится" к восстановлению экофизиологической “нормы”, причем этот процесс протекает более интенсивно в вариантах с внесением в почву микробов-антагонистов и фитопрепаратов, чем в контроле.

Результаты исследования показали изменение активности гидролаз почвы для разных вариантов опыта и в течение вегетации (табл. 3). Инвертаза катализирует гидролитическое расщепление сахарозы, что может в большей степени отражать плодородие и биологическую активность почв (Хазиев, 2005). В изучаемых нами вариантах активность инвертазы в июне (исключение составляет Смесь бактерий) возросла в 1.5 и 1.3 раза по сравнению с фоном и контролем соответственно. 
Таблица 3. Ферментативная активность и коэффициент гумификации (усредненные данные за вегетационный период) темно-серой почвы питомника в разных вариантах обработки 2016 г.

\begin{tabular}{l|l|c|c|c|c|c}
\hline \multicolumn{1}{c|}{ Вариант } & Инвертаза & Фосфатаза & Уреаза & $\begin{array}{c}\text { Полифенол } \\
\text { оксидаза }\end{array}$ & $\begin{array}{c}\text { Перокси } \\
\text { даза }\end{array}$ & $K_{\text {гум }}$ \\
\hline Фон (исходные условия) & 50.02 & 1.7 & 1.53 & 0.17 & 0.20 & 0.9 \\
Контроль (Н ${ }_{2}$ О) & 61.2 & 1.6 & 1.7 & 0.3 & 0.15 & 1.9 \\
ФП1 & 84.8 & 1.6 & 2.3 & 0.4 & 0.22 & 1.8 \\
ФП2 & 80.6 & 1.4 & 2.3 & 0.4 & 0.27 & 1.4 \\
ФП3 & 69.8 & 1.2 & 2.4 & 0.4 & 0.29 & 1.5 \\
ФП4 & 79.0 & 1.2 & 1.9 & 0.4 & 0.30 & 1.3 \\
ФП5 & 69.3 & 1.2 & 1.6 & 0.4 & 0.29 & 1.3 \\
Trichoderma harzianum & 73.0 & 1.9 & 1.9 & 0.3 & 0.28 & 1.2 \\
T. longibrachiatum & 73.5 & 1.8 & 2.2 & 0.4 & 0.23 & 1.59 \\
Смесь микромицетов & 76.7 & 1.5 & 1.7 & 0.4 & 0.18 & 2.3 \\
Bacillus aтуloliquеfaciens & 78.35 & 1.4 & 1.3 & 0.3 & 0.28 & 1.2 \\
Смесь бактерий & 50.9 & 1.8 & 1.3 & 0.32 & 0.31 & 1.1 \\
\hline
\end{tabular}

Примечание. $K_{\text {гум }}$ коэффициент гумификации (полифнолоксидаза : пероксидаза).

В сентябре при обработке семян сосны B. amyloliquefaciens и T. harzianum активность инвертазы возросла на 24 и $29 \%$, а при обработке ФП2 и ФП4 - на 6 и 15\%, соответственно. Отмечена обратная корреляционная связь между активностью инвертазы и численностью копиотрофов $(r=-0.5)$ и олиготрофов $(r=-0.7)$. Активность инвертазы была также связана с температурой и влажностью почвы $(r=-0.5$ и 0.5 соответственно), что согласуется с исследованиями (TrasarCepeda et al., 2008).

В исследуемой почве активность фосфатазы к концу вегетации (сентябрь) увеличилась на $50 \%$ в контроле и вариантах с фитопрепаратами (№№ 2-4) на 69, 14 и 17\%, в вариантах с микроорганизмами (T. longibrachiatum, $B$. amyloliquefaciens, Смесь бактерий) - на 50 и 33\% (табл. 3). Это может свидетельствовать об ускорении процессов мобилизации фосфора в почве и, тем самым, улучшении питания растений.

Через месяц после посева семян сосны активность уреазы в среднем увеличилась по сравнению с фоном на: $30 \%$ в контроле, $34 \%$ - при обработке фитопрепаратами, $19 \%$ - микромицетами и $2 \%$ - бактериями. Активность этого фермента в сентябре снизилась в почве опытных вариантов в среднем на 27\%. Исключение составили варианты с ФП4 и Смесью микромицетов, в которых активность фермента увеличилась на 15 и $48 \%$.

На скорость гидролиза мочевины в почве влияла температура $(r=-0.5-$ в июне и $r=0.5-$ в сентябре). Это согласуется с другими исследованиями, отмечавшими аналогичную тенденцию (Cortez et al., 1972). Прослеживается тенденция обратной связи активности уреазы с биомассой микроорганизмов в почве, о чем свидетельствуют коэффициенты корреляции между уреазой и МБ $(r=-0.5, p \leq 0.05)$. Выявлена также корреляция между активностью уреазы и другими ферментами при обработках семян микромицетами (с инвертазой $-r=-0.9$, с ПФО $-r=-0.8)$, фитопрепаратами (с инвертазой $-r=-0.6$ ) и бактериями (с ПФО и ПО $-r=-0.98)$.

Обработка семян сосны фитопрепаратами и микроорганизмами оказала положительное влияние на активность ПФО в почве. Так, через месяц после посева семян сосны активность этого фермента увеличилась во всех вариантах опыта по сравнению с фоном в 2 раза (табл. 3). Наиболее эффективными вариантами были ФП3, ФП5 и B. amyloliquefaciens. К сентябрю активность ПФО снизилась в контрольном варианте на 45\%, в вариантах с микроорганизмами на $22 \%$, в то время как в вариантах с фитопрепаратами осталась на том же уровне, что и в начале вегетации. На активность фермента также оказывали влияние влажность и содержание МБ ( $r=0.6$ и 0.5$)$.

Несколько иная картина изменения ферментативной активности почв на фоне фитопрепаратов отмечалась для пероксидазы. В июне активность ПО увеличивалась при обработке микроорганизмами и фитопрепаратами на 13 и $10 \%$, в контроле понизилась на $46 \%$ по сравнению с фоном. В сентябре активность фермента при обработке микроорганизмами и фитопрепаратами возросла в 1.5 раза по сравнению с июнем и прямо коррелировала с содержанием микробной биомассы $(r=0.7)$ и численностью олиготрофов $(r=0.5)$. 
(a)

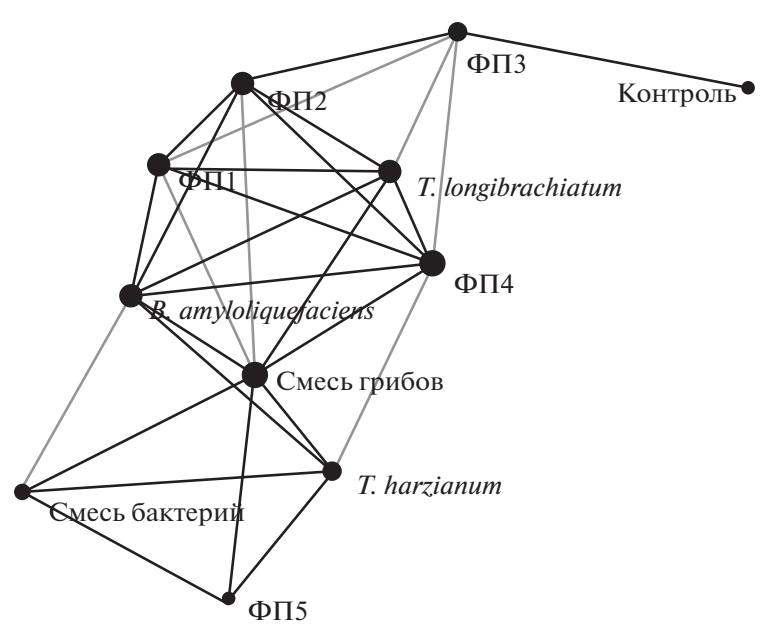

(б)

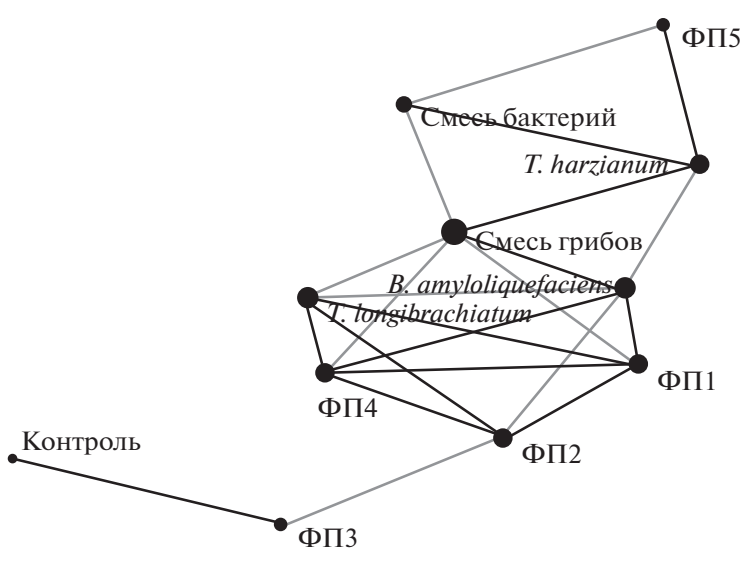

Рис. 2. Влияние способов обработки семян сосны на распределение биологических показателей почвы в зависимости от процента сходства между ними: (а) - при выборе в 60\%; (б) - распределение вариантов обработки семян сосны при $70 \%$ сходства между ними.

О преобладании катализируемых процессов в почве и синтезе собственно органического вещества судят по коэффициенту гумификации (Chertov et al., 2007). Исследования показали, что $K_{\text {гум }}$ после внесения в почву с семенами сосны микроорганизмов и фитопрепаратов был выше такового в изначальной (фоновой) почве в 2 раза, это свидетельствует о повышении интенсивности переработки органических веществ и синтезе гуминовых и фульвокислот после посева семян сосны обыкновенной (Титова, Козлов, 2012). В исследуемой почве не было отмечено достоверной разни-

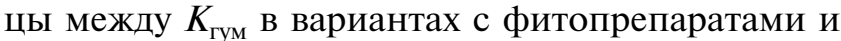
микроорганизмами; в среднем он составлял 1.9 в июне и 1.1 - в сентябре (табл. 3).

Таким образом, внесение в почву микроорганизмов-антагонистов и фитопрепаратов с семенами сосны обыкновенной способствовало увеличению активности ферментов класса гидролаз (инвертаза, уреаза фосфатаза) и оксидоредуктаз (полифенолоксидаза, пероксидаза) по сравнению с фоном. Обработка семян сосны микромицетами способствовала увеличению активности всех исследуемых ферментов (гидролаз и оксидоредуктаз), а бактериями - инвертазы, ПФО и ПО. Увеличение активности этих ферментов свидетельствует о сдвиге окислительно-восстановительных процессов, способствующих интенсивной переработке сахаров и фенолов в почве. Схожая тенденция отмечалась при обработке семян фитопрепаратами, в этом случае увеличивалась и активность уреазы. Наибольшее влияние на активность ферментов оказывала обработка штаммами-антагонистами $B$. amyloliquefaciens, $T$. harzianum и фитопрепаратами №№ 1, 2 и 4.
Анализ экспериментальных данных (Network plot, сети сходства) при $60 \%$ схожести выявил, что варианты обработки семян сосны по совокупности почвенных параметров разделились на две группы: первая - ФП5, T. harzianum, Смесь бактерий, вторая - ФП1, ФП2, ФП4 и T. longibrachiatum (рис. 2a). Сходство между вариантами обработки (узлами) в пределах этих групп выражено толщиной линий (ребер) связывающих их, что отражено графически на рис. 2а. Контроль находится на значительном расстоянии от других вариантов опыта (узлов) и не связан с ними графическими линиями (кроме ФП3). При увеличении процента схожести между исследуемыми вариантами до $70 \%$ наблюдается “выбивание” варианта ФП3 из общей сети (рис. 2б). Следовательно, наименьший эффект на показатели продуктивности почвы оказал вариант ФПЗ по сравнению с другими ФП. Кроме того, при $70 \%$ схожести всех вариантов обработки семян еще четче выделяются две группы: ФП5-T. harzianum-Смесь бактерий и ФП1-ФП2-ФП4-T. longibrachiatum, что подтверждает единообразное их влияние на почвенные параметры (МБ, БД,ЭКТГМ, рН и др.).

Результаты анализа Network plot были подтверждены кластерным анализом и методом главных компонент (рис. 3а, 3б). Показано, что массив данных, описывающий почвенные параметры в вариантах с внесением антагонистов или фитопрепаратов, образует конфигурацию “облако”, что свидетельствует об их однородности, в то время как варианты “контроль” и “ФП3” выявляются как "выбросы", являясь более изолированными кластерами (рис. 3а). Вертикальная дендрограмма (кластерный анализ) иллюстрирует объединение в один кластер вариантов обра- 
(a)

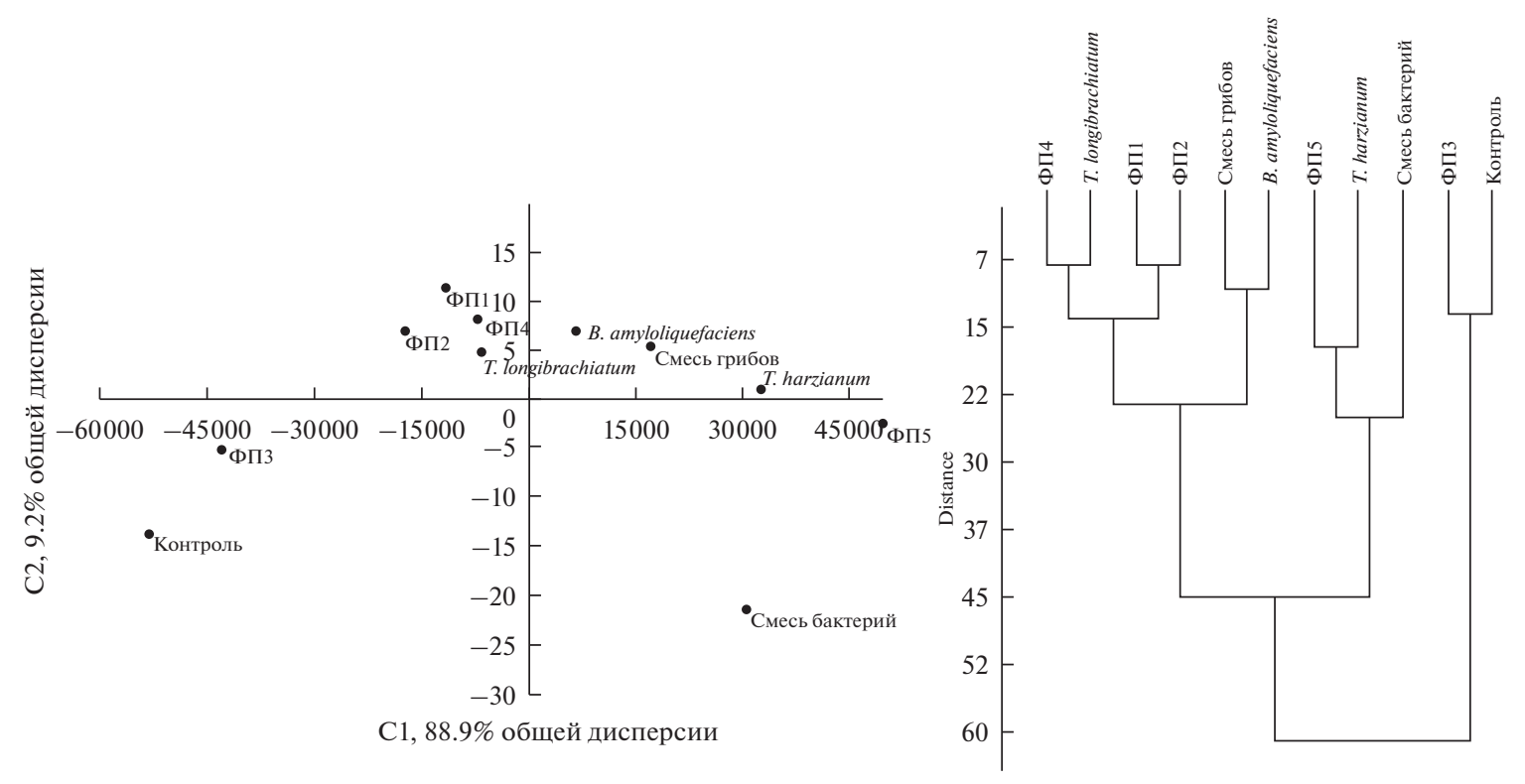

(б)

Рис. 3. Распределение биологических параметров почвы в зависимости от вариантов обработки семян сосны (а) - в разных плоскостях главных компонент; (б) - вертикальная древовидная диаграмма кластерного анализа расположения биологических показателей почвы при разных вариантах обработки семян сосны обыкновенной.

ботки ФП4 и T. longibrachiatum, ФП1 и ФП2 уже на втором шаге (на первом шаге каждое наблюдение представляет один кластер, вертикальная линия), что свидетельствует о наличии наибольшей схожести между ними - меньшее расстояние (рис. 3б). На третьем шаге объединяются в кластеры варианты "Смесь грибов" и "B. amyloliquefaciens", затем варианты "ФП3"-“Контроль” и "ФП5"-“T. harzianum”, на следующем шаге они образуют один большой общий кластер. Тот факт, что варианты “ФП3” и “Контроль” входят в этот большой кластер последними, подтверждает наличие существенных отличий почвенных условий в вариантах “ФПЗ” и "Контроль”.

Таким образом, внесение в почву микроорганизмов-антагонистов и фитопрепаратов способствовало увеличению содержания микробной биомассы, численности микроорганизмов, осуществляющих трансформацию органического вещества, и ферментативной активности, которое в то же время сопровождалось, уменьшением интенсивности микробного (базального) дыхания и удельного дыхания микробной биомассы (метаболического коэффициента). Внесение изученных микробных популяций в почву позволит увеличить продуктивность искусственно созданных фитоценозов, что, несомненно, улучшит качество и устойчивость лесопосадочного материала. K тому же восстановление деградированных почв лесных питомников путем внесения микроорганизмов-антагонистов с семенами хвойных дере- вьев будет соответствовать требованиям их экологичности, экономичности и безопасности.

\section{ВЫВОДЫ}

1. Обработка семян сосны обыкновенной микроорганизмами (T. harzianum, B. amyloliquefaciens) и фитопрепаратом на основе шелухи гречихи (ФП1) способствовала увеличению их всхожести и сохранности сеянцев по сравнению с контролем в среднем на $25 \%$.

2. Внесение бактерий (B. amyloliquefaciens, B. subtilis), микромицетов (T. harzianum, T. longibrachiatum) и фитопрепаратов (№№ 1, 2, 4) с семенами сосны увеличивало в почве питомника содержание микробной биомассы, численность микроорганизмов и активность ферментов в среднем в 1.4-2.2 раза по сравнению с контролем.

3. В почве исследуемых участков на протяжении периода вегетации доминировала олиготрофная группа микроорганизмов, что может свидетельствовать о снижении интенсивности микробной минерализации органического вещества.

4. Внесение Смеси бактерий, B. amyloliquefaciens, T. longibrachiatum и фитопрепаратов (№№ 1, $3,4)$ способствовало снижению удельного дыхания микробной биомассы, что может иллюстрировать “восстановление" функционирования микробного сообщества почвы опытного питомника.

Полученные данные могут быть использованы в практике лесного хозяйства для восстановления 
антропогенно-нарушенных или деградированных почв лесных фитоценозов. Авторы рекомендуют применять микроорганизмы-антагонисты в качестве биологических агентов, способных повышать грунтовую всхожесть семян, стимулировать рост и развитие сеянцев хвойных, увеличивать их сохранность, снижать вредоносность фитопатогенов, улучшать биологическую активность почв, что позволит повысить качество лесопосадочного материала в лесных питомниках Сибири.

\section{СПИСОК ЛИТЕРАТУРЫ}

Ананьева Н.Д. Микробиологические аспекты самоочищения и устойчивости почв. М.: Наука, 2003. 222 с.

Ананьева Н.Д., Сусьян Е.А., Гавриленко Е.Г. Особенности определения углерода микробной биомассы почвы методом субстрат-индуцированного дыхания // Почвоведение. 2011. № 11. С. 1327-1333.

Ананьева Н.Д., Сусьян Е.А., Рыжова И.М., Бочарникова E.O., Стольникова Е.В. Углерод микробной биомассы и микробное продуцирование двуокиси углерода дерново-подзолистыми почвами постагрогенных биогеоценозов и коренных ельников южной тайги (Костромская область) // Почвоведение. 2009. № 9. С. 1108-1116.

Антонов Г.И., Сорокин Н.Д., Барченков А.П., Кондакова О.Э. Оптимизация лесовыращивания с использованием биоконверсии древесно-опилочной массы в условиях Красноярской лесостепи // Лесоведение. 2018. № 1. С. 56-64.

Гродницкая И.Д., Сорокин Н.Д. Внесение микробовинтродуцентов в лесные почвы питомников Сибири // Почвоведение. 2007. № 3. С. 359-364.

Громовых Т.И., Литовка Ю.А., Андреева О.Н., Прудникова С.В, Корянова Т.А. Возбудители фузариоза в питомниках Красноярского края // Лесоведение. 2002. № 6. C. $68-71$.

Кондакова О.Э., Гродницкая И.Д. Оценка биологической активности музейных культур микроорганизмовантагонистов и их использование для предпосевной обработки семян сосны обыкновенной (Pinus sylvestris L.) in vitro // Вестник Томского государственного университета. Биология. 2018. № 42. С. 54-68.

Методы оценки бактериального разнообразия почв и идентификация почвенных бактерий / Под. ред. Лысак А.В. М.: Макс-Пресс, 2003. 120 с.

Методы почвенной микробиологии и биохимии / Под ред. Звягинцева Д.Г. М.: Изд-во Московского университета, 1991. $303 \mathrm{c.}$

Мишустин Е.Н., Емцев В.Т. Микробиология. М.: Агропромиздат, $1987.368 \mathrm{c}$.

Новосельцева А.И., Смирнов В.А. Справочник по лесным питомникам. М.: Лесн. пром., 1983. 280 с.

Практикум по микробиологии / Под ред. Нетрусова А.И. M.: Academia, $2005.603 \mathrm{c}$.

Рожанская О.А., Королев К.Г., Ломовский О.И., Юдина Н.В., Сероклинов Г.В. Регуляция морфогенеза нута (Cicer arietinum L.) продуктами механической актива- ции и электромагнитными излучениями // Сибирский вестник сельскохозяйственной науки. 2007. № 9. C. $45-50$.

Сорокин Н.Д., Гродницкая И.Д., Шапченкова О.А., Евграфова С.Ю. Экспериментальная оценка устойчивости почвенного микробоценоза при химическом загрязнении // Почвоведение. 2009. № 6. С. 701-707.

Стольникова Е.В., Ананьева Н.Д., Чернова О.В. Микробная биомасса, ее активность и структура в почвах старовозрастных лесов европейской территории России // Почвоведение. 2011. № 4. С. 479-494.

Титова В.И., Козлов А.В. Методы оценки функционирования микробоценоза почвы, участвующего в трансформации органического вещества // Изд-во Нижегородская с.-х. академия. Нижний Новгород: 2012. $64 \mathrm{c}$.

Фомина Н.В., Демиденко Г.А., Сорокин Н.Д. Экологомикробиологический мониторинг почвы лесного питомника Красноярского края // Вестник КрасГАУ. 2006. № 10. С. 146-152.

Хазиев Ф.Х. Методы почвенной энзимологии. М.: Наука, 2005. 252 с.

Anderson J.P.E., Domsch K.H. A physiological method for the quantitative measurement of microbial biomass in soils // Soil Biology and Biochemistry. 1978. V. 10. № 3. P. 314-322.

Anderson T.H., Domsch K.H. Application of ecophysiological quotients $\left(q \mathrm{CO}_{2}\right.$ and $\left.\mathrm{qD}\right)$ on microbial biomasses from soils of different cropping histories // Soil Biology and Biochemistry. 1990. V. 22. № 2. P. 251-255.

Baset M.A., Shamsuddin Z.H., Wahab Z., Marziah M. Effect of plant growth promoting rhizobacterial (PGPR) inoculation on growth and nitrogen incorporation of tissue-cultured Musa plantlets under nitrogen-free hydroponics condition // Australian J. Crop Science. 2010. № 4(2). P. 85-90.

Chertov O.G., Komarov A.S., Nadporozhskaya M.A. Analysis of the dynamics of plant residue mineralization and humification in soil // Eurasian Soil Science. 2007. V. 40. № 2. P. 140-148.

Cortez J., Lossaint P., Billes G. Biological activity of soils in the Mediterranesh ecosystems // III Enzymatic activities. Review of Ecology. 1972. № 9. P. 1-2.

Gibbs P.A., Chambers B.J., Chaudri A.M. Initial results from long-term field studies at three sites on the effects of heavy metal-amended liquid sludges on soil microbial activity // Soil Use Manag. 2006. V. 22. № 2. P. 180-187.

Harris J.A. Measurements of the soil microbial community for estimating the success of restoration // European J. Soil Science. 2003. V. 54. P. 801-808.

Rovira A.D., Macura J., Vancura V. Effects of Azotobacter, Bacillus and Clostridium on the growth of wheat // Plant Microbes Relationships. 1965. P. 193-200.

Solevic T., Novakovic M., Ilic M., Antic M., Vrvic M.M., Jovancicevic $B$. Investigation of the bioremediation potential of aerobic zymogenous microorganisms in soil for crude oil biodegradation // Journal of the Serbian Chemical Society. 2011. V. 76. P. 425-438.

Trasar-Cepeda C., Leirós M.C., Gil-Sotres F. Hydrolytic enzyme activities in agricultural and forest soils. Some implications for their use as indicators of soil quality // Soil Biology Biochemistry. 2008. V. 40. P. 2146-2155. 


\title{
The Effect of Treatment of Scots Pine Seeds by Microorganisms and Phytopreparations on the Seedling Safety and Soil Properties in a Forest Nursery
}

\author{
O. E. Pashkeeva1, *, I. D. Grodnitskaya ${ }^{1}$, G. I. Antonov' ${ }^{1}$, O. I. Lomovsky ${ }^{2}$, and I. I. Gaidasheva ${ }^{3}$ \\ ${ }^{1}$ Sukachev Institute of Forest of SB RAS, Akademgorodok, 50/28, Krasnoyarsk, 660036 Russia \\ ${ }^{2}$ Institute of Solid State Chemistry and Mechanochemistry SB RAS, Kutateladze, 18, Novosibirsk, 630128 Russia \\ ${ }^{3}$ Siberial federal university, prospect Svobodnii, 79, Krasnoyarsk, 660041 Russia \\ *E-mail: koeandkoe@mail.ru
}

\begin{abstract}
The studies were carried out on the experimental farm "Pogorelsky bor" of the Sukachev Institute of Forest, SB RAS. The effect of pre-sowing treatment of Scots pine seeds (Pinus sylvestris L.) by aqueous suspensions of indigenous microorganisms with antagonistic activity towards phytopathogens and phytopreparations obtained from plant materials on soil biogenicity (microbial biomass and enzymatic activity) and safety of coniferous seedlings was studied in model field experiments. Strains of micromycetes Trichoderma harzianum, Trichoderma longibrachiatum, Trichoderma lignorum and their mixture (T. harzianum, T. longibrachiatum, T. lignorum); Bacteria Bacillus amyloliquefaciens, their mixture (B. amyloliquefaciens, B. subtilis, Pseudomonas sp.), five phytopreparations were variants of Scots pine seed treatments. It was shown that the pre-sowing treatment of Scots pine seeds contributed to the improvement of their germination, preservation of seedlings by the end of the vegetation season, and improved morphometric parameters of the seedlings compared with the control by $24.5 \%$ on the average. The bacteria and micromycetes introduced with the seeds increased the productivity and biogenicity of the forest nursery soil by 1.3-2.0 times. It was established that the oligotrophic group of microorganisms prevailed in the control soil throughout the vegetation season, while the hydrolyticcopyotrophic group of microorganisms prevailed after the treatment of Scots pine seeds with microorganisms and phytopreparations two months after sowing seeds. The introduction of antagonist microbes (B. amyloliquefaciens, T. longibrachiatum, and a mixture of bacteria) and phytopreparations also favorably affected the restoration of the ecophysiological norm of functioning of the soil microbial community (returning the value of the microbial metabolic coefficient to the background ones). A 2-fold decrease in the values of the microbial metabolic coefficient $\left(q \mathrm{CO}_{2}\right)$ was observed in the soil of the studied areas. The obtained results can be recommended for using in forestry practice when growing coniferous seedlings.
\end{abstract}

Keywords: Krasnoyarsk forest-steppe, conifer seedlings, experimental forest nursery, antagonist microorganisms, phytopreparations, mechanochemical processing of plant materials.

\section{REFERENCES}

Anan'eva N.D., Mikrobiologicheskie aspekty samoochishcheniya i ustoichivosti pochv (Microbiological aspects of soil self-purification and stability), M.: Nauka, 2003, 222 p.

Anan'eva N.D., Sus'yan E.A., Gavrilenko E.G., Determination of the soil microbial biomass carbon using the method of substrate-induced respiration, Eurasian Soil Science, 2011, Vol. 44, No. 11, pp. 1215-1221.

Anan'eva N.D., Sus'yan E.A., Ryzhova I.M., Bocharnikova E.O., Stol'nikova E.V., Microbial biomass carbon and the microbial carbon dioxide production by soddy-podzolic soils in postagrogenic biogeocenoses and in native spruce forests of the southern taiga (Kostroma oblast), Eurasian Soil Science, 2009, Vol. 42, No. 9, pp. 1029-1037.

Anderson J.P.E., Domsch K.H., A physiological method for the quantitative measurement of microbial biomass in soils, Soil Biology and Biochemistry, 1978, Vol. 10, No. 3, pp. 215-221.

Anderson T.-H., Domsch K.H., Application of eco-physiological quotients $q \mathrm{CO}_{2}$ and $q \mathrm{D}$ on microbial biomasses from soils of different cropping histories, Soil biology and biochemistry, 1990, Vol. 22, No. 2, pp. 251-255.

Antonov G.I., Sorokin N.D., Barchenkov A.P., Kondakova O.E., Optimizatsiya lesovyrashchivaniya s ispol'zovaniem biokonversii drevesno-opilochnoi massy v uslovi- yakh Krasnoyarskoi lesostepi (Optimisation of silviculture using bioconversion of sawdust pulp in Krasnoyarsk foreststeppe), Lesovedenie, 2018, No. 1, pp. 56-64.

Baset M.A., Shamsuddin Z.H., Wahab Z., Marziah M., Effect of plant growth promoting rhizobacterial (PGPR) inoculation on growth and nitrogen incorporation of tissuecultured Musa plantlets under nitrogen-free hydroponics condition, Australian J. Crop Science, 2010, No. 4(2), pp. 85-90.

Chertov O.G., Komarov A.S., Nadporozhskaya M.A., Analysis of the dynamics of plant residue mineralization and humification in soil, Eurasian Soil Science, 2007, Vol. 40, No. 2, pp. 140-148.

Cortez J., Lossaint P., Billes G., Biological activity of soils in the Mediterranesh ecosystems, III Enzymatic activities. Review of Ecology, 1972, No. 9, pp. 1-2.

Fomina N.V., Demidenko G.A., Sorokin N.D., Ekologomikrobiologicheskii monitoring pochvy lesnogo pitomnika Krasnoyarskogo kraya (Ecological and microbiological monitoring of the soil of the forest nursery of Krasnoyarsk region), Vestnik KrasGAU, 2006, No. 10, pp. 146-152.

Gibbs P.A., Chambers B.J., Chaudri A.M., Initial results from long-term field studies at three sites on the effects of heavy metal-amended liquid sludges on soil microbial activity, Soil Use Manag., 2006, Vol. 22, No. 2, pp. 180-187. 
Grodnitskaya I.D., Sorokin N.D., Application of microbes to the soils of Siberian tree nurseries, Eurasian Soil Science, 2007, Vol. 40, No. 3, pp. 329-334.

Gromovykh T.I., Litovka Y.A., Andreeva O.N., Prudnikova S.V., Koryanova T.A., Vozbuditeli fuzarioza v pitomnikakh Krasnoyarskogo kraya (Fusarium causative agents in nurseries of the Krasnoyarsk Territory), Lesovedenie, 2002, No. 6, pp. 68-71.

Harris J.A., Measurements of the soil microbial community for estimating the success of restoration, European J. Soil Science, 2003, Vol. 54, pp. 801-808.

Khaziev F.K., Metody pochvennoi enzimologii (Methods of soil enzymology), M.: Nauka, 2005, 251 p.

Kondakova O.E., Grodnitskaya I.D., Otsenka biologicheskoi aktivnosti muzeinykh kul'tur mikroorganizmov-antagonistov i ikh ispol'zovanie dlya predposevnoi obrabotki semyan sosny obyknovennoi (Pinus sylvestris L.) in vitro (Biological activity assessment of museum cultures of antagonist microorganisms and their use for presowing treatment of Scots pine seeds (Pinus sylvestris L.) (in vitro)), Vestnik Tomskogo gosudarstvennogo universiteta. Biologiya, 2018, No. 42, pp. 54-68.

Metody otsenki bakterial'nogo raznoobraziya pochv i identifikatsiya pochvennykh bakterii (Methods for assessing bacterial diversity of soils and identification of soil bacteria), M.: Maks-Press, 2003, 120 p.

Metody pochvennoi mikrobiologii i biokhimii, (Methods of soil microbiology and biochemistry), M.: Izd-vo Moskovskogo universiteta, 1991, 303 p.

Mishustin E.N., Emtsev V.T., Mikrobiologiya (Microbiology), M.: Agropromizdat, 1987, 368 p.

Novosel'tseva A.I., Smirnov V.A., Spravochnik po lesnym pitomnikam (Handbook of forest nurseries), M.: Lesn. prom., 1983, $280 \mathrm{p}$.
Praktikum po mikrobiologii (Practicum in microbiology), M.: Akademiya, 2005, 603 p.

Rovira A.D., Macura J., Vancura V., Effects of Azotobacter, Bacillus and Clostridium on the growth of wheat, Plant Microbes Relationships, 1965, pp. 193-200.

Rozhanskaya O.A., Korolev K.G., Lomovskii O.I., Yudina N.V., Seroklinov G.V., Regulyatsiya morfogeneza nuta (Cicer arietinum L.) produktami mekhanicheskoi aktivatsii i elektromagnitnymi izlucheniyami (Regulation of chickpea (Cicer arietinum L.) morphogenesis by means of mechanoactivated materials and electromagnetic radiation), Sibirskii vestnik sel'skokhozyaistvennoi nauki, 2007, No. 9, pp. 45-50.

Solevic T., Novakovic M., Ilic M., Antic M., Vrvic M.M., Jovancicevic B., Investigation of the bioremediation potential of aerobic zymogenous microorganisms in soil for crude oil biodegradation, J. Serbian Chemical Society, 2011, Vol. 76, pp. 425-438.

Sorokin N.D., Grodnitskaya I.D., Shapchenkova O.A., Evgrafova S.Y., Experimental assessment of the microbocenosis stability in chemically polluted soils, Eurasian Soil Science, 2009, Vol. 42, No. 6, pp. 650-656.

Stolnikova E.V., Ananyeva N.D., Chernova O.V., The microbial biomass and its activity and structure in the soils of old forests in the European Russia, Eurasian Soil Science, 2011, Vol. 44, No. 4, pp. 437-452.

Titova V.I., Kozlov A.V., Metody otsenki funktsionirovaniya mikrobotsenoza pochvy, uchastvuyushchego $v$ transformatsii organicheskogo veshchestva (Methods for assessing the functioning of soil microbocenosis involved in the transformation of organic matter), Nizhny Novgorod: Izd-vo Nizhegorodskaya s.-kh. akademiya, 2012, 64 p.

Trasar-Cepeda C., Leirós M.C., Gil-Sotres F., Hydrolytic enzyme activities in agricultural and forest soils. Some implications for their use as indicators of soil quality, Soil Biology and Biochemistry, 2008, Vol. 40, No. 9, pp. 2146-2155. 